\section{DIAGNOSING THE DEAD}

I was concerned by the editorial 'Diagnosing the dead: the retrospective analysis of genetic disease' by AR Rushton published recently in the College Journal (V $R$ Coll Physicians Edinb 2013; 43:II-4). As an editorial this paper must reflect the current views, policy and beliefs of the Editorial Department, if not the College itself.

The section of particular concern is that labelled 'mental illness and the British Royal Family'. Rushton claims that King George III, his ancestors, family members and descendants suffered from variegate porphyria. Rushton clearly has not studied and does not cite primary sources or the literature, both past and present, that find this view quite unsubstantiated. Thus when Ida Macalpine and her son Richard Hunter made the fraudulent claim in the British Medical Journal in the 1960s, ${ }^{1,2}$ several experienced porphyria clinicians and researchers found considerable errors with this claim: Charles Dent, Geoffrey Dean, Archie Cochrane, Lennox Eales to name but a few. None of this is cited or referenced in the editorial.

Recent re-evaluation following a detailed review of the British Library primary sources by Peters and colleagues has clearly shown gross distortion of the medical and other reports of the King's behaviour during his four to five episodes of mental illness by Rushton and his fellow travellers. These findings have been reported in leading peer reviewed journals including the Journal of the Royal College of Physicians of Edinburgh itself; ${ }^{3-10}$ none of these references is cited by Rushton.

In view of the current interest in the nature of the King's illness and the consequences of a diagnosis of bipolar disorder (manic depressive psychosis), first put forward in $1855^{11}$ and subsequently confirmed ${ }^{5,12-14}$ including the revised online Oxford Dictionary of National Biography, corrections to the editorial must be put in place.

It seems that the refereeing of editorials in this Journal is seriously wanting and hopefully this will be reviewed, corrected and reported to the readership: the provenance and peer review status of editorials, reports must be stated.

Perhaps the recent evidence ${ }^{15}$ of Ida Macalpine's (Hirschmann) medical retraining in Edinburgh in the 1930s, further emphasises the need for due diligence?

TJ Peters

Institute of Archaeology and Antiquity, University of Birmingham

Email timothy@ironlock.f2s.com

\section{References}

I Macalpine I, Hunter R. The "insanity" of King George III: a classic case of porphyria. Br Med J 1966; I: 65-7I.
2 Macalpine I, Hunter R, Rimington C. Porphyria in the Royal houses of Stuart, Hanover, and Prussia. A follow-up study of George IIl's illness. Br Med J 1968; I: 7-18.

3 Peters TJ. The madness of King George III: revelations by James Bland Burges of Nantcribba, Montgomeryshire. Montgomeryshire Collections 2009; 97: 63-7I.

4 Peters TJ, Wilkinson D. King George III and porphyria: a clinical re-examination of the historical evidence. Hist Psychiatry 2010;21:3-19.

5 Peters TJ, Beveridge A. The madness of King George III: a psychiatric re-assessment. Hist Psychiatry 2010; 21: 20-37.

6 Peters TJ, Beveridge A. The blindness, deafness and madness of King George III: psychiatric interactions. J R Coll Physicians Edinb 2010: 40: 8I-5.

7 Peters TJ. King George III, bipolar disorder, porphyria and lessons for historians. Clin Med 20I I; I I: 26I-4.

8 Garrard P, Peters TJ. Multiple sclerosis or neuromyelitis optica? Re-evaluating an 18th century illness using 2 Ist century software. JRSM Short Rep 2012; 3: I-4.

9 Peters TJ, Garrard P, Ganesan V et al. The nature of King James VI/I medical condition: new approaches to the diagnosis. Hist Psychiatry 2012; 23: 277-90.

10 Peters T], Garrard P. Computer-based diagnosis in historical persons.J R Coll Physicians Edinb 2013: 43: I6I-8.

II Ray I.The insanity of King George III. Am J Insanity I855; I2: I-29.

12 Guttmacher MS. America's last king. An interpretation of the madness of George III. New York: Charles Scribner's Sons; I94I.

13 Guttmacher MS. The "insanity" of George III. Bull Menninger Clinic 1964; 28: 101-18.

14 Brownstein S. George III: a revised view of the royal malady. J History Neurosciences 1997; 6: 38-49.

15 Dingwall HM. The Triple Qualification examination of the Scottish medical and surgical colleges, 1884-1993.J R Coll Physicians Edinb 2010; 40: 269-76

Editor's reply: The purpose of an editorial is to engage, inform, stimulate and on occasion provoke. The editorial policy of the Journal is stated clearly on our contents page: 'articles and editorials should not be taken to represent the policy or opinion of the RCPE unless this is specifically stated'.

\section{COMPUTER-BASED DIAGNOSIS OF ILLNESS IN HISTORICAL PERSONS}

The article on computer diagnosis of illness in historical personages' was most interesting but I fear that too much reliance is being placed on it with considerable disregard for historical factors.

The database has presumably been based on twentieth/ twenty-first century patients living in today's rational, secular and relatively prosperous society and the diagnosis based on observations by highly trained clinicians and scientists so the data from previous ages must be by necessity inadequate. The mindset and cultural ambiance of, for example a sixteenth/seventeenth century monarch, a believer in witchcraft and the divine right of kings, must of necessity have been different.

Historical knowledge is also helpful. One of the criteria mentioned for diagnosis of Lesch-Nyan syndrome in James VI and I is the lack of empathy with his mother. 
This is hardly surprising as he was separated from her before he was one year old, his tutor George Buchanan considered her responsible for the death of James' father, ${ }^{2}$ and his overriding wish was to succeed Queen Elizabeth of England. A league with England was concluded in 1586, accompanied by an English pension for James and an assurance that Elizabeth would not oppose his claims to the English throne unless he provoked her. ${ }^{3}$ To be fair to him he did have his mother re-buried in Westminster Abbey after he became King of England.

Similarly, misuse of alcohol is regarded as a diagnostic feature - but I presume by modern guidelines, of doubtful application in the seventeenth century. Maladaptive behaviour is said to be another criterion but after all he did manage to survive the extremely difficult transition from King of Scots to King of England!

The only historians quoted are distinctly hostile to James in contrast to more recent authors such as Gordon Donaldson and Antonia Fraser who are more favourable. One might as well quote Sellars and Yeatman, those underrated historians 'James the first slobbered at the mouth and had favourites. He was thus a bad king.'4

None of this is to deny that computer programmes can be of help in the diagnosis of historical figures but it should be recognised that these were designed for today's patients and can lead to errors unless taken in conjunction with historical events and different cultural backgrounds. This point is actually made in the paper but the authors have not followed their own advice.

\section{G Ferguson}

Retired Consultant Physician

\section{References}

I Peters TJ, Garrard P. Computer-based diagnosis of illness in historical persons.J R Coll Phycisians Edinb 2013; 43:161-8. http:// dx.doi.org// 0.4997/JRCPE.2013.2/5

2 Donaldson G. James VI and vanishing frontiers. In: Menzies G. The Scottish nation. London: BBC; 1972. p. 107.

3 Ferguson W. The Identity of the Scottish nation. Edinburgh: Edinburgh University Press; 1998. p. 94.

4 Sellars WC, Yeatman RJ. 1066 and all that.York: Methuen; 1999. p. 69.

\section{Author's reply}

Our review was intended as a summary and discussion of the novel application of computer-based diagnostics based on a presentation to the Edinburgh History of Medicine Group on 7 December 2011 and applied several methods to a wide range of individuals. It was therefore necessary to introduce summaries for the individual case studies although an extensive bibliography was supplied. Dr Ferguson's criticisms were directed only at our studies on King James $\mathrm{VI} / \mathrm{l}$ and therefore it was surprising that he did not read the relevant publications by our group on this subject ${ }^{1,2}$ or the techniques used ${ }^{3,4}$ or the clinical features of the diagnosis supplied. ${ }^{5}$ This simple requirement would have rendered his letter superfluous and irrelevant.

The Whiggish approach ${ }^{6}$ to historical diagnosis advocated by Ferguson may apply to non-medical social behaviours but is much less likely to be applicable to the identification of inherited metabolic disease. Indeed, it is important to note that the motivation for our study of James $\mathrm{VI} / \mathrm{I}$ was the specious claim made by, among others, Antonia Fraser, that he, his mother and grandfather all suffered from variegate porphyria! It should be noted that the most likely diagnosis for James listed in the SimulConsult differential diagnosis was mild attenuated Lesch-Nyhan disease, clinically quite distinct from classical LeschNyhan disease. ${ }^{5}$

In no way can lack of 'empathy with his mother' be considered a criterion for mild attenuated Lesch-Nyhan disease as stated by Ferguson. Lack of empathy may reflect the autistic behaviour of James and is best illustrated by the attitude and responses of James to the execution of his mother. ${ }^{7}$ Similarly, alcohol misuse is not a 'diagnostic feature' for Lesch-Nyhan disease though it may be a feature of Asperger's syndrome. These points are fully referenced in our paper in History of Psychiatry. ${ }^{2}$ Although mild attenuated Lesch-Nyhan disease may be accompanied by autistic features, additional causal factors that may be implicated include perinatal complications $^{8}$ and maternal depression, ${ }^{9}$ well reported by Antonia Fraser. ${ }^{10}$

It is quite incorrect of Ferguson to state that we have only 'quoted historians distinctly hostile to James'. A glance at our full paper shows that we cited over 30 publications reporting various aspects of James's behaviour, as well as discussions with leading Scottish authorities on James and his immediate relatives.

Perhaps if Ferguson had taken the time to read the material referenced by our paper, he would have realised that his criticisms were unfounded.

\section{References}

I Garrard P, Stephenson J, Ganesan V et al. Attenuated variants of Lesch-Nyhan disease: the case of King James VI/I. Brain 20I0; 133:e I53. http://dx.doi.org//0.1093/brain/awq I56

2 Peters TJ, Garrard P, Ganesan V et al. The nature of King James VI/ls medical conditions: new approaches to the diagnosis. Hist Psychiatry 2012; 23:277-90. http://dx.doi.org/ I0.I I77/0957 I54XI I4284I3

3 Segal M, Leber S. The impact of computer resources on child neurology. In: Swaiman KF, Ashwal S, Ferriero DM et al, editors. Pediatric neurology: principles and practice. 5th ed. New York: Mosby; 2012. p. 275.

4 Ben-Cohen S, Wheelwright S, Robinson J et al. The adult Asperger assessment (AAA): a diagnostic method. J Autism \& Dev Disord 2005; 35:807-19. http://dx.doi.org/10.1007/s I 0803-005-0026-5

5 Jinnah HA, Ceballos-Picot I, Torres RJ et al. Attenuated variants of Lesch-Nyhan disease. Brain 2010; 133:67I-89. http://dx.doi. org/l0.1093/brain/awq013 
6 Butterfield H. The Whig interpretation of history. New York:W.W. Norton; 1965.

7 Raits RS, Cameron Al (eds). King James's secret: negotiations between Elizabeth and James VI, relating to the execution of Mary Queen of Scots, from the Warrender papers. London: Nisbet \& Co. Ltd; 1927.

8 Gillberg C, Cederlund M.Asperger syndrome: familial and pre- and perinatal factors. J Autism Dev Disord 2005; 35: 159-66. http://dx.doi org/I0.1007/s I0803-004-1993-7

9 Rai D, Lee BK, Dalman C et al. Parental depression, maternal antidepressant use during pregnancy, and risk of autism spectrum disorders: population based case-control study. BMJ 2013 346:f2059. http://dx.doi.org// $0.1136 / \mathrm{bmj}$. f2059

10 Fraser A. Mary Queen of Scots. London:World Books; 1970.

TJ Peters, P Garrard

\section{WHAT MAKES A SPECIALIST A SPECIALIST?}

I read with interest the survey reported by Drs Dobb and Cooper investigating decisions by acute medicine and emergency medicine staff in managing patients presenting with a history in keeping with subarachnoid haemorrhage ( $R$ Coll Physicians 20I3; 43:207-14). The results were certainly eye-opening.

I note that in their conclusions they refer to emergency and acute medicine physicians as 'non-specialists' in the investigation of such patients. An element of inferiority is thus implied when comparing such doctors to physicians working in other hospital departments. Patients come to hospital for specialist assessment, and this is what should be provided by physicians in emergency and acute medicine. Consultants in these disciplines must be listed on the General Medical Council's Specialist Register to work in the NHS, and are thus unquestionably specialists in their own right.

All hospital consultants are specialists in their own fields. Terminology that suggests otherwise should be avoided since it is confusing for patients and potentially damaging to professional relationships.

PK Hamilton

Belfast Health and Social Care Trust

Email paul.hamilton@belfasttrust.hscni.net

\section{Authors' reply}

In 1996 Professors Robert Wachter and Lee Goldman famously coined the term 'the Hospitalist' in the New England Journal of Medicine' to describe a developing specialty of doctors able to save insurance companies inpatient beds and money, a 'spin' they both later regretted and replaced with an emphasis on patient safety and quality of care. ${ }^{2}$ The American Hospitalist is now a very well established specialty, respected, and with a considerable research and evidence base. The UK followed a similar path with Acute Medicine becoming a recognised specialty in $200 \mathrm{I}$, although a separate training programme did not arise until 2009.

In the UK, most 'specialists' will be referred only a select group of inpatients, most often with a clear diagnosis. The assessment, investigation and management of acute undifferentiated illness are core to the role of the acute care physician, and those practising in emergency medicine. The importance of experienced doctors with skill in discerning the salient points from the patient history and examination; knowledge of the properties of the tests they order; and a talent for Bayesian thinking to inform safe clinical decision is vital to the delivery of acute medical care.

We think this is undervalued in some circles and may be a dying art. Our use of the term 'non-specialist' was merely to point out we are not doctors with day to day experience and training in the post diagnosis management of subarachnoid haemorrhage, and certainly was not intended to imply, as you suggest, an element of inferiority.

\section{References}

I Wachter RM, Goldman L.The emerging role of 'hospitalists' in the American health care system. New Engl J Med 1996; 335:5I4-7. http://dx.doi.org/I0.I056/NEJMI99608I533507I3

2 Wachter RM, Flanders S. The hospitalist movement and the future of academic general internal medicine. J Gen Intern Med 1998; I3:783-5. http://dx.doi.org/I0.I046/j.I525-I497.I998.00234.x

B Dobb, J Cooper

Please note that opinions expressed in Letters to the Editor should not be taken as those of the Editorial team or the Royal College of Physicians of Edinburgh. 